\title{
Publisher embargo
}

Bo-Christer Björk, David Solomon

\section{Source}

https://wellcome.ac.uk/sites/default/files/developing-effective-market-for-open-accessarticle-processing-charges-mar14.pdf Bo-Christer Björk and David Solomon. (2014). Developing an Effective Market for Open Access Article Processing Charges (Report). Wellcome Trust.

A period after which an author, in the copyright agreement with the publisher, is allowed to self-archive an OA version of the manuscript of an article in a repository. 